\title{
Comparison of rapid plasma reagin card test and venereal disease research laboratory test in the detection of biological false positive reactions in systemic lupus erythematosus
}

\author{
BONNIE B. DORWART AND ALLEN R. MYERS \\ University of Pennsylvania School of Medicine, Philadelphia, Pa. 19104, U.S.A.
}

The importance of a biological false positive reaction in the diagnosis of systemic lupus erythematosus is attested by its inclusion as one of the fourteen preliminary diagnostic criteria for that disease recently described by a committee of the American Rheumatism Association (Cohen, Reynolds, Franklin, Kulka, Ropes, Shulman, and Wallace, 1971). Because of its simplicity many clinical laboratories now employ the rapid plasma reagin (RPR) card test (Portnoy, Brewer, and Harris, 1962) exclusively as their standard screening test for syphilis or for biological false positive reactions.

Therefore, recent reports that the RPR card test detects fewer biological false positive reactions than the venereal disease research laboratory (VDRL) test (Scotti, Mackey, and Trautman, 1970; Garner and Backhouse, 1972) were disturbing, and raised the possibility that exclusive use of the RPR test might result in lack of detection of this important clue to the diagnosis of systemic lupus erythematosus. Comparison of these two serological tests in patients with systemic lupus erythematosus, other connective tissue diseases, and controls allowed us to answer this question.

\section{Material and methods}

Sera from 74 patients with connective tissue diseases, of whom 41 had systemic lupus erythematosus by American Rheumatism Association criteria (Cohen and others, 1971), were tested by the same examiner who was unaware of the clinical diagnoses. RPR and VDRL tests were performed on sera which had been frozen at $-70^{\circ} \mathrm{C}$. for up to $36 \mathrm{mths}$. The sera were thawed immediately before being tested. Aliquots on which the VDRL test was to be performed were inactivated at $56^{\circ} \mathrm{C}$. for $30 \mathrm{~min}$. and tested as specified by the U.S. Department of Health, Education and Welfare (1969). RPR card tests were performed by the method of Portnoy and others (1962) on unheated portions of sera without the examiner's knowledge of the result of the VDRL test on the same sample.

Received for publication March 5, 1974
The RPR $18 \mathrm{~mm}$. circle card test kit supplied by Hynson, Westcott, and Dunning Inc. (Baltimore, Maryland, U.S.A.) was employed. All reactive specimens were serially diluted and titres obtained.

No patient whose serum was reactive by the VDRL or RPR test had any clinical evidence of syphilis and all were found to be negative on fluorescent treponemal antibody absorption testing. In each case, the biological false positive reaction was present for longer than 6 mths.

Also tested in an identical manner and received blindly by the examiner were nineteen sera from blood donors at the Hospital of the University of Pennsylvania and 23 sera found to be positive on fluorescent treponemal antibody absorption and RPR testing in the serology laboratory at the Hospital of the University of Pennsylvania.

\section{Results}

These are shown in the Table. The RPR card test detected one more biological false positive reaction in a patient with systemic lupus erythematosus than did the VDRL. When this result became known, further aliquots of the original serum from this patient were resubmitted to the examiner, and both tests were repeated. Again the RPR test was reactive $1: 2$ and the VDRL test non-reactive. No prozone

TABLE Detection by RPR and VDRL tests of chronic biological false positive reactions in patients with connective tissue diseases and controls

\begin{tabular}{|c|c|c|c|}
\hline Diagnosis & $\begin{array}{l}\text { No. of } \\
\text { patients }\end{array}$ & $\begin{array}{l}\text { Reactive } \\
R P R\end{array}$ & $\begin{array}{l}\text { Reactive } \\
\text { VDRL }\end{array}$ \\
\hline Systemic lupus erythematosus & 41 & 6 & 5 \\
\hline Rheumatoid arthritis & 23 & 1 & 1 \\
\hline Scleroderma & 1 & $\mathbf{0}$ & $\mathbf{0}$ \\
\hline Polymyositis & 3 & $\mathbf{0}$ & $\mathbf{0}$ \\
\hline Discoid lupus erythematosus & 1 & $\mathbf{0}$ & $\mathbf{0}$ \\
\hline Vasculitis of unknown aetiology & 1 & 0 & $\mathbf{0}$ \\
\hline Polychrondritis & 1 & $\mathbf{0}$ & $\mathbf{0}$ \\
\hline Sarcoid & 1 & $\mathbf{0}$ & $\mathbf{0}$ \\
\hline Sjögren's syndrome & 1 & 0 & $\mathbf{0}$ \\
\hline Raynaud's disease & 1 & 0 & $\mathbf{0}$ \\
\hline Syphilis & 23 & 23 & 23 \\
\hline Healthy blood donors & 19 & 0 & 0 \\
\hline
\end{tabular}


phenomenon could be found using the VDRL method on this specimen.

Titres found with the two tests were not comparable, but all titres were relatively low with both methods ( $\leqq 1: 8$ ).

All sera from blood donors were nonreactive by both tests. All known syphilitic sera were reactive by both methods, with titres greater than $1: 16$ in all samples.

\section{Discussion}

We conclude that the RPR card test is as sensitive as the VDRL test, if not more so, in detecting a biological false positive reaction in systemic lupus erythematosus. It would not appear to be unduly sensitive, however, since the incidence of biological false positive reactions in our study using the RPR test was 15 per cent., which is comparable to the previously reported incidence of 10-20 per cent. in most series (Montgomery and McCreight, 1949; Zellmann, 1952).

\section{Summary}

A comparison of the RPR and VDRL tests was undertaken in order to determine whether the RPR card test might miss some biological false positive reactions for syphilis in cases of systemic lupus erythematosus, as it does in leprosy. Sera from 41 patients with systemic lupus erythematosus were tested with both of these methods. The RPR was as sensitive as the VDRL test, and thus would appear to be a valid procedure for the detection of biological false positive reactions in patients with systemic lupus erythematosus.

\section{References}

Cohen, A. S., Reynolds, W. E., Franklin, E. C., Kulka, J. P., Ropes, M. W., Shulman, L. E., and WALLACE, S. L. (1971) Bull. rheum. Dis., 21, 643

GARNER, M. R., and BACKHOUSE, J. L. (1972) f. clin. Path., 25, 786

MONTGOMERY, H., and MCCreight, W. G. (1949) Arch. Derm., 60, 356

Portnoy, J., Brewer, J. H., and Harris, A. (1962) Publ. Hlth Rep. (Wash.), 77, 645

Scotti, A. T., Mackey, D. M., and Trautman, J. R. (1970) Arch. Derm., 101, 328

U.S. Department of Health, Education and Welfare (1969) 'Manual of Tests for Syphilis', p. 33. Public Health Service Publication No. 411. Washington, D.C.

Zellmann, H. E. (1952) Amer. F. Syph., 36, 163

Comparaison du test plasmatique de réagine sur carte (RPR) et du test du Venereal Disease Research Laboratory pour mettre en évidence les réactions biologiques faussement positives dans le lupus érythémateux "systémique"

\section{SOMMAIRE}

On entreprit une comparaison des tests RPR et VDRL dans le but de déterminer si le RPR sur carte pouvait laisser passer quelques réactions biologiques faussement positives pour la syphilis en cas de lupus érythémateux systémique, comme ceci s'observe dans la lèpre. L'une et l'autre méthode fut employée sur les sérums de 41 malades atteints de lupus érythémateux systémique. Le RPR fut aussi sensible que le VDRL et se montra ainsi un procédé approprié pour la détection des réactions biologiques faussement positives chez les malades atteints de lupus érythémateux systémique. 